\title{
Epidemiological evaluation of concordance between initial diagnosis and central pathology review in a comprehensive and prospective series of sarcoma patients in the Rhone-Alpes region
}

\author{
Antoine Lurkin*1,2, Francoise Ducimetière 1,2, Dominique Ranchère Vince1, Anne-Valérie Decouvelaere1, \\ Dominic Cellier7, François N Gilly4', Dimitri Salameire5, Pierre Biron1,2,3, Guy de Laroche3,4,5,6, Jean Yves Blay1,2,3,4,5,7,8 \\ and Isabelle Ray-Coquard1,2
}

\begin{abstract}
Background: Sarcomas are rare malignant tumors. Accurate initial histological diagnosis is essential for adequate management. We prospectively assessed the medical management of all patients diagnosed with sarcoma in a European region over a one-year period to identify the quantity of first diagnosis compared to central expert review (CER).

Methods: Histological data of all patients diagnosed with sarcoma in Rhone-Alpes between March 2005 and Feb 2006 were collected. Primary diagnoses were systematically compared with second opinion from regional and national experts.

Results: Of 448 patients included, 366 (82\%) matched the inclusion criteria and were analyzed. Of these, 199 (54\%) had full concordance between primary diagnosis and second opinion (the first pathologist and the expert reached identical conclusions), 97 (27\%) had partial concordance (identical diagnosis of conjonctive tumor but different grade or subtype), and 70 (19\%) had complete discordance (different histological type or invalidation of the diagnosis of sarcoma). The major discrepancies were related to histological grade $(n=68,19 \%)$, histological type $(n=39,11 \%)$, subtype $(n=17,5 \%)$, and grade plus subtype or grade plus histological type ( $n=43,12 \%)$.

Conclusions: Over $45 \%$ of first histological diagnoses were modified at second reading, possibly resulting in different treatment decisions. Systematic second expert opinion improves the quality of diagnosis and possibly the management of patients.
\end{abstract}

\section{Background}

Sarcomas are malignant tumors developing in soft tissue, bone, skin or internal organs. The large majority of soft tissue tumors are benign and 100 times more common than malignant lesions [1,2]. Because there are more than 50 histological subtypes of soft tissue sarcoma (STS) identified in the 2002 WHO classification, accurate diagnosis is difficult [3]. Given the rarity of the disease, inappropriate medical management has been reported in

* Correspondence: lurkin@lyon.fnclcc.fr

1 Centre Léon Bérard, 28 rue Laennec - 69008 Lyon; France

Full list of author information is available at the end of the article more than $70 \%$ of patients with sarcomas [4]. Careful pretreatment evaluation is therefore essential for accurate diagnosis and appropriate treatment decision making $[5,6]$. Discrepancies between pathologists have been reported frequently [7-10]. Although immunohistochemistry, Fluorescence In Situ Hybridization (FISH) and molecular biology can facilitate diagnosis, these techniques are not routinely available in all laboratories and their use requires experienced pathologists with expertise in molecular biology.

Second opinion in diagnostic pathology has recently received considerable attention as a result of efforts to 
enhance institutional performance and reduce medical errors [11]. However, the mechanisms by which second opinion is obtained greatly influence the results [12]. Second opinions given by another institution or a specialty panel at the time of patient referral produce highly discordant rates as compared to analysis of cases referred to experts for review [13]. In the case of expert review, discrepancies are not viewed as "errors" but as a reflection of the acknowledged need for assistance. For this we initiated an exhaustive, prospective study involving the systematic comparison of initial histological diagnosis by a first ('non-expert') pathologist and second opinion (SO) from regional and/or national experts of the disease in a comprehensive population of patients diagnosed in a precise geographical region over a one-year period.

\section{Methods}

\section{Objectives}

The main objective of the present work was to evaluate the benefit of systematic central review by regional and national experts of all sarcoma cases diagnosed in the Rhône-Alpes region (RA). All sarcoma cases diagnosed by pathologists of the region were reported, and data were statistically analyzed to quantify inter-observer differences and determine their nature.

\section{Description of the Region}

RA is the second largest region in France, with nearly 6 million inhabitants and 8 departements (i.e. the administrative and geographical unit in France). It has 15 public structures (3 university hospitals, 1 cancer center, 11 general hospitals) with 59 pathologists and 28 private structures with 80 pathologists.

\section{Patient selection}

To be eligible, patients had to meet the following inclusion criteria: first diagnosis of connective tissue tumor, according to the $2002 \mathrm{WHO}$ definition, and no previous treatment, first sarcoma diagnosis between March 1, 2005 and February 28, 2006 in RA region, all disease stages, and age $\geq 15$ years. Exclusion criteria were as follows: diagnosis of relapse or a diagnosis other than sarcoma (i.e. low grade phyllodes tumor). Similarly, patients were not included when primary diagnosis had been established in the reference center (Leon Berard Cancer Center) by one of the 'experts' or if the tumor specimen was not sent to the expert or when there was not enough tumor material. In order to include patients and assess the concordance our study obtained an ethical approval by a review board (CNIL: Commission Nationale de l'information et des libertés. Independent administrative authority protecting privacy and personal data). The evaluation of medical records has been made through clinical audit

\section{Study design}

The goal of this study was to compare initial histological evaluation by the diagnostic pathologist (generally not an expert on these diseases) and results of the central expert review (CER) by two regional and national exclusively soft tissue experts. These two experts, members of the French Sarcoma Group (FSG), were selected by the EMS project scientific committee. All pathologists working in the region agreed to cooperate. All suspected cases of sarcoma (soft tissue, bone and visceral tissue sarcoma; $\mathrm{n}=$ 671) diagnosed during the reference period were collected [14].

For each patient, a copy of the original histology report and histopathological specimens (Hemalin Eosin Safran (HES) and paraffin-embedded tissue) representative of the tumor sample were provided.

The diagnostic pathologist was offered financial compensation for each patient included (50 euros). For all included patients, immunohistochemistry (and/or molecular biology analysis) was performed by the referent pathologist.

\section{Exhaustiveness control}

To ensure exhaustiveness, several controls were established throughout the study by comparing the registered patients with the complete list of: 1) sarcomas reviewed by the expert pathologist every two months during the inclusion period; 2) medical files of the multidisciplinary sarcoma committee and patients obtained from the Medical Information Department of the reference center; 3) pediatric patients with sarcoma to confirm the number of patients aged 15-18 and obtained from the pediatric registry of the RA region; 4) all sarcomas diagnosed by initial pathologists; then we excluded patients with exclusion criteria. After cross validation, only 5 additional patients were identified as missing and included $[15,16]$.

\section{Main outcome measure}

Differences between the first diagnosis established by the non-expert pathologist and the second opinion given by experts were evaluated and scored on a three-point scale: The two experts evaluated in same time the diagnosis.

Zero agreement corresponded to cases where initial diagnosis was benign and final diagnosis was malignant (sarcoma) or conversely, or where the tumor was classified in different histological subtypes (i.e. synovialosarcoma vs. liposarcoma).

Partial agreement corresponded to cases where both pathologists diagnosed a sarcoma but with different histopathological grades, or with a different subtype (i.e. dedifferentiated liposarcoma vs. myxoid round cell liposarcoma).

Full agreement corresponded to cases where both observers gave identical diagnoses. 
To define this score, the two experts must conclude to the same diagnose. In some rare cases and when the two experts did not have the same conclusion or if the diagnose was difficult the diagnosis was reexamined either by another expert (international expert Pr Fletcher) or/and discussed at monthly FSG pathologist meetings and a final consensus was determinated.

For all sarcoma types with mutation, a molecular biology was systematically assessed (FISH technic, PCR or DNA sequencing) to characterize the genetic alteration and confirm the diagnose. The Immunomarques were systematically done again by the expert

\section{Grading system}

The grading system of the French Sarcoma Group of the French Federation of Cancer Centers (FNCLCC) was used in this study as now proposed in the WHO classification [17]. Grade was rated 'not applicable' for some specific histological types (e.g. Kaposi sarcoma) or when the grade could not be determined (biopsy specimen).

\section{Subgroup analysis}

For all included cases, the pathologist investigators were systematically offered an expert second opinion and the discrepancies were analyzed. However, two groups of patients were distinguished. The first one ("requested SO" group) corresponded to patients examined by a "non expert" pathologist who requested a second opinion from experts to confirm initial diagnosis. The second group ("control" group) included patients whose tumor samples were analyzed by a 'non expert' pathologist who did not request confirmation of diagnosis by experts and whose findings were reviewed only in the context of the present project but the results were not disclosed.

\section{Statistical analysis}

To evaluate patient characteristics and diagnostic concordance, categorical data were analyzed using Pearson's $\chi^{2-}$ test or Fisher's exact test, as appropriate. Continuous data were analyzed with Student's $t$-test. The statistical significance level was set at $p=0.05$ in a two-sided test.

Comparisons were also made between the "requested SO" group and controls. The $X^{2}$ test was used to determine the rate of concordance and the types of discordance. Correlations between the most frequent causes of error and groups were analyzed using the Kappa test. For grading evaluation, a two by two table was constructed to compare original diagnosis against final diagnosis, both subsets being partitioned according to whether or not the diagnosis was the type of sarcoma under consideration. A Kappa test was used to measure agreement between initial diagnosis and expert review as compared to what would be expected by chance alone $[18,19]$. All analyses were performed using $\operatorname{SPSS}^{\circ}$ (version 12.0) and SAS ${ }^{\circ}$ softwares.

\section{Results}

All values reported hereafter for grade, histology and type or site of sarcoma are those obtained after expert review.

\section{Characteristics of selected patients and tumors}

Of 671 patients initially screened by pathology laboratories, 220 (33\%) were excluded, either because of patient age $<15(n=26,4 \%)$, local relapse $(n=92,14 \%)$, metastatic relapse $(n=40,6 \%)$, or because the patient had not been firstly diagnosed in RA ( $n=36,5 \%)$ or had not been diagnosed between March 2005 and Feb 2006 ( $n=26$, $4 \%)$. Among the 451 selected patients, 52 (12\%) were further excluded because initial diagnosis had been established in the reference center by one of the experts. Of the 399 remaining patients, 29 (7\%) were excluded because there was no or not enough tumor tissue available for a second histological analysis and 4 (1\%) because the initial histological report was not available. Finally, 366 (92\%) patients were eligible for final analysis (Figure 1). The first diagnosis of sarcoma was performed in private practice for 265 (72\%) patients and in public laboratories for 101 (28\%) patients. Only 2 laboratories did not recruit any patient.

\section{Characteristics of included patients and tumors}

Patients' characteristics are reported in Table 1. Among the 366 analyzed patients, 184 were males (50\%) and 182 were females (50\%). Median age was 61 years (range, 1592): 60 (range, 15-92) for males and 63 (range, 16-91) for females.

\section{Concordance analysis}

Concordance analysis was performed on 93 (25\%) sarcoma biopsy specimens and 273 (75\%) surgical samples. Concordance data regarding grade, type of tumor sample (biopsy vs. surgery) and type of laboratory (private vs.

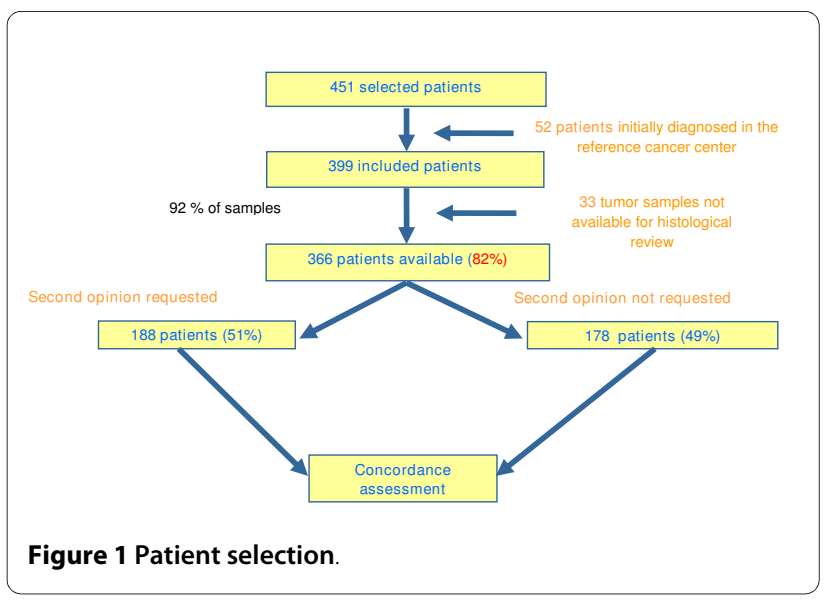


Table 1: Characteristics of included patients

\begin{tabular}{|c|c|c|}
\hline & Number & $\%$ \\
\hline Included patients & 366 & $100 \%$ \\
\hline \multicolumn{3}{|l|}{ Types of sarcoma } \\
\hline Soft tissue & 215 & 59 \\
\hline Visceral tissue & 130 & 35 \\
\hline Bone tissue & 21 & 6 \\
\hline \multicolumn{3}{|l|}{ Tumor site } \\
\hline Abdomen & 101 & 27.6 \\
\hline Lower limb & 76 & 20.8 \\
\hline Thorax & 54 & 14.8 \\
\hline Pelvis & 45 & 12.3 \\
\hline Upper limb & 34 & 9.3 \\
\hline Head and Neck & 29 & 7.9 \\
\hline Retroperitoneum & 21 & 5.7 \\
\hline Multiple localizations & 5 & 1.4 \\
\hline Axial skeleton & 1 & 0.3 \\
\hline \multicolumn{3}{|l|}{ Histological subtype } \\
\hline GIST & 65 & 17.8 \\
\hline Liposarcoma & 56 & 15.3 \\
\hline NOS Sarcoma * & 52 & 14.2 \\
\hline Other ${ }^{* *}$ & 38 & 10.3 \\
\hline Leiomyosarcoma & 26 & 7.1 \\
\hline Dermatofibrosarcoma protuberans & 20 & 5.5 \\
\hline Kaposi sarcoma & 18 & 4.9 \\
\hline Uterine leiomyosarcoma & 12 & 3.3 \\
\hline Myxofibrosarcoma & 12 & 3.3 \\
\hline Osteosarcoma & 11 & 3.0 \\
\hline Angiosarcoma & 10 & 2.7 \\
\hline Chondrosarcoma & 9 & 2.5 \\
\hline PNET/Ewing sarcoma & 8 & 2,2 \\
\hline Rhabdomyosarcoma & 8 & 2.2 \\
\hline Synovial sarcoma & 7 & 1,9 \\
\hline $\begin{array}{l}\text { Unclassified malignant connective } \\
\text { tumors }\end{array}$ & 14 & 3.8 \\
\hline \multicolumn{3}{|l|}{ Grade } \\
\hline 1 & 85 & 23.2 \\
\hline$\|$ & 77 & 21.0 \\
\hline III & 97 & 26.5 \\
\hline Not applicable ${ }^{* * *}$ & 103 & 28.1 \\
\hline Unknown & 4 & 1.1 \\
\hline
\end{tabular}

* NOS $=$ not otherwise specified.

**The 'other' category included sarcoma subtypes with less than 5 patients and tumors initially described as sarcomas and reclassified by the experts as carcinomas or sarcomatoid carcinomas

**Not applicable (Kaposi sarcoma, for instance) 
public) are given in Table 2. Concordance analysis showed 70 cases of zero agreement (19\%), 97 partial agreements (27\%) and 199 full agreements (54\%). The rate of discordance was higher in grade II-III than in grade I tumors $(p=0.012)$. On the other hand, no significant differences were reported according to type of tumor sample, type of laboratory and molecular biology examination (yes vs. no) (Table 2). The molecular biology techniques used were the Fluorescence in situ hybridization (FISH), the PCR and DNA sequencing.

Causes of non-concordance are presented in Table 3. Discrepancies between initial diagnosis and review were essentially related to grade and histological subtype. Details of zero and partial agreements are given in Table 4 and Additional File 1, respectively. More precisely, in the zero concordance group, the diagnoses were changed from benign to malignant for 7 patients. The modification of diagnosis between malignant tumor and benign have been concerning 3 patients. The most frequent dis- crepancy was related to the grade of the tumor: either no grading by the diagnostic pathologist while the expert attributed grade $3(n=33,20 \%)$, or misinterpretation of the grading with grade 3 attributed by the diagnostic pathologist and grade 1 by the expert $(n=3,2 \%)$. Other $(\mathrm{n}=131,78 \%)$ discrepancies were related to the grade $(0$ vs. I, I vs. II, II vs. III) and histological subtype. We measured the chance-corrected agreement on grade between groups using the Kappa test. The Kappa coefficient was 0.7857 ( $\mathrm{p}<0.0001$ ), which reflected a high level of agreement. The major cause of discrepancies was the very high proportion $(\mathrm{n}=85,66 \%)$ of tumors not graded by diagnostic pathologists. However, when diagnostic pathologists did grade the tumors, their grading was generally correct (Additional File 1).

The second most frequent discrepancy was related to the histological type (Table 4). In 22 (31\%) patients the diagnosis reviewed and modified by the expert concerned benign tumor or sarcomatoid carcinoma.

Table 2: Concordance analysis

\begin{tabular}{|c|c|c|c|c|}
\hline Concordance & Zero & Partial & Full & $p$ \\
\hline Included tumors & $70(100 \%)$ & $97(100 \%)$ & 199 (100\%) & \\
\hline \multicolumn{5}{|l|}{ Type of laboratory } \\
\hline Public & $17(16.8 \%)$ & $28(27.7 \%)$ & $56(55.4 \%)$ & 0.78 \\
\hline Private & $53(20 \%)$ & $69(26 . \%)$ & $143(54 \%)$ & \\
\hline Concordance & Zero & Partial & Full & $\boldsymbol{p}$ \\
\hline Included tumors & 70 & 97 & 97 & \\
\hline \multicolumn{5}{|l|}{ Type of tumor sample } \\
\hline Biopsy & $16(17.2 \%)$ & $23(24.7 \%)$ & $54(58.1 \%)$ & 0.70 \\
\hline $\begin{array}{l}\text { Surgical } \\
\text { specimen }\end{array}$ & $54(19.8 \%)$ & $74(27.1 \%)$ & $145(53.1 \%)$ & \\
\hline Concordance & Zero & Partial & Full & $\boldsymbol{p}$ \\
\hline Included tumors & 44 & 81 & 134 & \\
\hline \multicolumn{5}{|l|}{ Grade } \\
\hline I & $9(10.6 \%)$ & $21(24.7 \%)$ & $55(64.7 \%)$ & 0.01 \\
\hline II-III & $35(20.1 \%)$ & $60(34.5 \%)$ & 79 (45.4\%) & \\
\hline Concordance & Zero & Partial & Full & $p$ \\
\hline Included tumors & 67 & 97 & 199 & \\
\hline \multicolumn{5}{|l|}{$\begin{array}{l}\text { Molecular biology } \\
\text { study }\end{array}$} \\
\hline No & $45(20 \%)$ & $61(26 . \%)$ & 127 (54\%) & 0.84 \\
\hline Yes & $23(17.6 \%)$ & $36(27.5 \%)$ & 72 (55.0\%) & \\
\hline
\end{tabular}


Table 3: Reasons for non-concordance

\begin{tabular}{|c|c|c|}
\hline Reasons for non-concordance & Frequency & $\%$ \\
\hline Grade & 68 & 18.5 \\
\hline Histological type & 39 & 10.7 \\
\hline Grade and Histological type & 30 & 8.2 \\
\hline Subtype & 17 & 4.6 \\
\hline Grade and subtype & 13 & 3.6 \\
\hline SUB-TOTAL & 167 & 45.6 \\
\hline Patient with total agreement & 199 & 54.4 \\
\hline TOTAL & 366 & 100 \\
\hline
\end{tabular}

Diagnosis was confirmed by molecular biology (RTPCR, FISH) in 131 (36\%) patients: 72 (55\%) in the "requested SO" group and $59(45 \%)$ in the control group at the request of the expert reviewer. Seventy-two (55\%) tests were performed in the group with full concordance, 36 (27\%) with partial concordance and 23 (18\%) with zero concordance. Eighty-seven (66\%) of these 131 molecular biology tests were positive, 32 (24\%) were negative and 12 (9\%) were non significant. They were performed essentially in patients with GIST ( $\mathrm{n}=41,31 \%)$, liposarcoma ( $\mathrm{n}$ $=39 ; 30 \%)$ and dermatofibrosarcoma protuberans $(\mathrm{n}=$ $11,8 \%$ ). Final diagnosis could not be established by the first expert for 20 (5\%) patients, and the case was submitted to other sarcoma experts for second opinion (French sarcoma group).

\section{Requested SO group versus control group}

For the two groups of patients distinguished, the characteristics are compared in Tables 5 and Additional File 2.

Only three items seemed different between subgroups: type of samples, type of laboratory and histological subtype. The patients for whom initial diagnosis had been made from biopsy specimens were most frequently not proposed for a SO. Likewise, the majority of patients included in the group without $\mathrm{SO}$ were first diagnosed in public laboratories. For all other factors no differences were noted. In fact, non expert pathologists asked for a second expert opinion principally for difficult diagnoses or cases requiring molecular analysis $(\mathrm{n}=188)$. Sex, age, type of tumor, or tumor localization and grade did not influence the decision of the first pathologist to request a second opinion (Table 5).

\section{Concordance results in the two subgroups of patients}

The concordance observed between the two groups of patients is described in Table 6. Not surprisingly, concordance was significantly better in cases where the primary pathologist did not ask for a second opinion as compared to cases where an expert second opinion was requested spontaneously $(66 \%$ vs. $44 \%)(p<0.001)$. Reasons for non-concordance were tested in both groups. The type of sample and the type of laboratory were not found correlated to concordance, with respectively $40(70 \%)$ vs. 77 $(63 \%)(p=0.62)$, and $82(68 \%)$ vs. $35(60 \%)(p=0.39)$ full concordance in the group without SO. In the group with SO, full concordance results were $14(39 \%)$ vs. $68(44 \%)(\mathrm{p}$ $=0.72)$ and $61(42 \%)$ vs. $21(48 \%)(p=0.66)$.

\section{Discussion}

Full concordance was reported for only $54 \%$ of cases included in this comprehensive cohort of sarcoma patients treated in RA in one year. Indeed, accurate diagnosis is essential to ensure appropriate management of patients with sarcoma, especially in the context of new targeted therapies. This study confirmed that centralized pathological review improves the quality of diagnosis in these rare tumors.

This study confirms that the diagnosis of sarcoma is very difficult to establish since more than $45 \%$ of first diagnoses were declared invalid by the panel of experts conducting the centralized pathological review. The major result was that concordance seems independent of the type of laboratory providing the primary diagnosis, the nature of the tumor samples or the tissue affected by the sarcoma (bone, soft tissue, viscera). The most frequent discrepancies identified were related to tumor grade and histological type. Exact determination of the tumor type and grade is crucial for making individual treatment decisions and subsequently improving patient outcome $[20,21]$. In fact, determining the grade of the tumor is essential to decide between adjuvant chemotherapy or not, neo-adjuvant chemotherapy or not, or radiotherapy or not. With the introduction of targeted treatments and the proliferation of clinical studies, patients whose grade has not been correctly evaluated may be excluded from trials [20-23]. Although the clinical practice recommendations published in France have confirmed that the tumor grade must be included in the his- 
Table 4: Diagnostic differences in cases with zero concordance

\begin{tabular}{|c|c|c|}
\hline Expert diagnosis & Initial diagnosis & $\begin{array}{c}\text { Frequency } \\
(n=70)\end{array}$ \\
\hline NOS Sarcoma & MPNST & 1 \\
\hline NOS Sarcoma & Angiosarcoma & 1 \\
\hline NOS Sarcoma & Unclassified malignant tumor & 6 \\
\hline NOS Sarcoma & Leiomyosarcoma & 1 \\
\hline NOS Sarcoma & GIST & 1 \\
\hline NOS Sarcoma & Chondrosarcoma & 1 \\
\hline NOS Sarcoma & Embryonic Rhabdomyosarcoma & 1 \\
\hline NOS Sarcoma & Benign Tumor & 1 \\
\hline NOS Sarcoma & Liposarcoma & 1 \\
\hline NOS Sarcoma & Leiomyosarcoma & 2 \\
\hline Leiomyosarcoma & Benign Tumor & 2 \\
\hline Leiomyosarcoma & NOS Sarcoma & 1 \\
\hline Osteosarcoma & NOS Sarcoma & 1 \\
\hline Osteosarcoma & Unclassified malignant tumor & 1 \\
\hline Osteosarcoma & Melanoma & 1 \\
\hline Lipoma-like Liposarcoma & Benign Tumor & 1 \\
\hline Lipoma-like Liposarcoma & Fibrosarcoma & 1 \\
\hline Lipoma-like Liposarcoma & Unclassified malignant tumor & 1 \\
\hline Liposarcoma & Benign Tumor & 1 \\
\hline Liposarcoma & NOS Sarcoma & 2 \\
\hline Dedif. Liposarcoma & Leiomyosarcoma & 2 \\
\hline Dedif. Liposarcoma & Unclassified malignant tumor & 1 \\
\hline Dedif. Liposarcoma & NOS Sarcoma & 1 \\
\hline Myxofibrosarcoma & Liposarcoma & 1 \\
\hline Myxofibrosarcoma & NOS Sarcoma & 3 \\
\hline Myxofibrosarcoma & Sarcomatoid Carcinoma & 1 \\
\hline Myxofibrosarcoma & Chondrosarcoma & 1 \\
\hline Sarcomatoid Carcinoma & Leiomyosarcoma & 1 \\
\hline Sarcomatoid Carcinoma & NOS Sarcoma & 3 \\
\hline Angiosarcoma & Unclassified malignant tumor & 1 \\
\hline Angiosarcoma & Synovial sarcoma & 1 \\
\hline Benign Tumor & Inflammatory MyxofibroSarcoma & 1 \\
\hline Benign Tumor & Leiomyosarcoma & 1 \\
\hline Benign Tumor & $\begin{array}{l}\text { Well-differenciated lipoma-like } \\
\text { Liposarcoma }\end{array}$ & 1 \\
\hline Epithelioid Sarcoma & Unclassified malignant tumor & 1 \\
\hline Epithelioid Sarcoma & Synovial sarcoma & 1 \\
\hline PNET/Ewing sarcoma & Carcinoma & 2 \\
\hline PNET/Ewing sarcoma & Unclassified malignant tumor & 3 \\
\hline Rhabdomyosarcoma & Leiomyosarcoma & 1 \\
\hline GIST & NOS Sarcoma & 1 \\
\hline Carcinoma & Phyllodes Tumor & 1 \\
\hline
\end{tabular}


Table 4: Diagnostic differences in cases with zero concordance (Continued)

\begin{tabular}{lll}
\hline Carcinoma & NOS Sarcoma & 1 \\
Solitary fibrosis/malignant Tumor & GIST & 1 \\
Uterine Leiomyosarcoma & Benign Tumor & 1 \\
PEComa & Unclassified malignant tumor & 1 \\
Fibrosarcoma & Unclassified malignant tumor & 1 \\
Endometrial Stromal Sarcoma & Leiomyosarcoma & 1 \\
Epithelioid Hemangioendothelioma & Carcinoma & 1 \\
Inflammatory Myxofibrosarcoma & Epithelioid Sarcoma & 1 \\
Unclassified malignant tumor & Carcinoma & 1 \\
Low grade fibromyxoid Sarcoma & Benign Tumor & 1 \\
Kaposi sarcoma & NOS Sarcoma & 1 \\
Synovial sarcoma & Benign Tumor & 1 \\
Dermatofibrosarcoma protuberans & Benign Tumor & 1 \\
\hline NOS: not otherwise specified & & 1 \\
PNET: primitive neuroectodermal tumor & & 1 \\
GIST: gastrointestinal stromal tumor & & 1 \\
MEComa: malignant perivascular epithelioid cell tumor & & \\
\end{tabular}

tological report generated at the time of diagnosis, this information is not always given, as confirmed in other studies demonstrating that the reproducibility of grade is very difficult to achieve [20,23-25]. On the other hand, when non expert pathologists participating in the study did grade a tumor, their evaluation was generally correct. Pathologists may sometimes lack experience and would benefit from training sessions organized in the framework of continuous medical education [26].

Accurate determination of the type of sarcoma lesion is also crucial for correct patient management especially for differentiating between benign and malignant tumors, or between the different subtypes [27]. Determining the grade of the tumor is more reproducible than characterizing its histological type which is the second cause of diagnostic discordance [8]. The second cause of discrepancies concerned the histological type, and the central question that arises is whether all sarcoma cases should be reviewed in a specialized center. Importantly, all pathologists evaluating sarcoma patients should be able to use immunohistochemistry for confirmation of diagnosis. For certain histological types (GIST, Dermatofibrosarcoma protuberans...), molecular biology can also contribute to the establishment and/or the confirmation of diagnosis [28-32]. Non concordance between first diagnosis and review seems very frequent for liposarcoma, PNET tumor and NOS sarcoma, and it is high for GIST and dermatofibrosarcoma protuberans for which specific markers are available. Similar results were reported by Harris et al, with a high degree of agreement for osteosarcoma and chondrosarcoma and low agree- ment for leiomyosarcoma and malignant fibrous histiocytoma $[27,28]$.

In the literature, the rate of diagnostic errors in patients with soft tissue sarcoma is between $25 \%$ and $40 \%$. [610,33-37], Surprisingly, since the first published reports on second opinion for sarcoma tumors in 1980, despite the introduction of new tools (immunochemistry, molecular biology etc.) and the development of educational workshops, the percentage of concordance has remained unchanged. Disagreements between diagnostic pathologists and expert panel members are inescapable (unrepresentative samples, heterogeneous tumors, misdiagnosis of grading...). In spite of the relatively high incidence of sarcoma, such variations in diagnosis will continue to occur and no significant convergence can be expected over time [14]. Our comprehensive prospective study confirmed the results of previous retrospective studies, with inconsistencies between primary diagnosis and histological review in $45 \%$ of all cases. Our results revealed that diagnostic pathologists were often lack expertise in this disease or in other rare tumors. Thus, systematic expert second opinion seems essential [35]. The inexperience of non-specialists with the multitude and complexity of soft tissue sarcomas is probably the most important factor accounting for diagnostic discrepancies [27]. Actually, this question of centralized diagnosis is less relevant for tumors with more "standardized" diagnosis and management, like carcinoma or ovarian cancer [38,39].

In this study, $50 \%$ of the tumors were spontaneously addressed for a second opinion by the non-expert pathologist, versus only $40 \%$ in a previous study[25]. All pathol- 
Table 5: Patient characteristics per subgroup

Patient characteristics.

\begin{tabular}{|c|c|c|c|}
\hline & requested SO group & Control group & $p$ \\
\hline Included patients & $188(100 \%)$ & $178(100 \%)$ & \\
\hline \multicolumn{4}{|l|}{ Sex } \\
\hline Males & $102(54.3 \%)$ & $82(46.1 \%)$ & 0.117 \\
\hline Females & $86(45.7 \%)$ & $96(53.9 \%)$ & \\
\hline \multicolumn{4}{|l|}{ Age (years) } \\
\hline Mean & 57.9 & 59.6 & \\
\hline Median & 62 & 61 & 0.359 \\
\hline Range & {$[15-86]$} & {$[18-92]$} & \\
\hline \multicolumn{4}{|l|}{ Types of tumor } \\
\hline Soft tissue & $117(62.2 \%)$ & $98(55.1 \%)$ & \\
\hline Bone tissue & $13(6.9 \%)$ & $8(4.5 \%)$ & 0.128 \\
\hline Visceral tissue & $58(30.9 \%)$ & $72(40.4 \%)$ & \\
\hline \multicolumn{4}{|l|}{ Localization } \\
\hline Upper limb & 15 (8.\%) & $19(10.7 \%)$ & \\
\hline Lower limb & 45 (23.9\%) & $31(17.4 \%)$ & \\
\hline Abdomen & $44(23.4 \%)$ & $57(32 \%)$ & \\
\hline Thorax & $31(16.5 \%)$ & $23(12.9 \%)$ & 0.313 \\
\hline Head and Neck & $16(8.5 \%)$ & $13(7.3 \%)$ & \\
\hline Pelvis & $25(13.3 \%)$ & $20(11.2 \%)$ & \\
\hline Retroperitoneum & $10(5.3 \%)$ & $11(6.2 \%)$ & \\
\hline Axial skeleton & $1(0.5 \%)$ & $0(0 \%)$ & \\
\hline Multiple localizations & $1(0.5 \%)$ & $4(2.2 \%)$ & \\
\hline \multicolumn{4}{|l|}{ Grade } \\
\hline Grade I & $47(25 \%)$ & $38(21.3 \%)$ & \\
\hline Grade II & $36(19.1 \%)$ & $41(23 \%)$ & \\
\hline Grade III & $50(26.6 \%)$ & $47(26.4 \%)$ & 0.716 \\
\hline Non applicable & $52(27.2 \%)$ & $51(28.7 \%)$ & \\
\hline Unknown & $3(1.6 \%)$ & $1(0.6 \%)$ & \\
\hline \multicolumn{4}{|l|}{ Histological subtypes } \\
\hline Liposarcoma & $37(19.7 \%)$ & $19(10.7 \%)$ & \\
\hline NOS Sarcoma & $32(17.0 \%)$ & $20(11.2 \%)$ & \\
\hline GIST & $23(12.2 \%)$ & $42(23.6 \%)$ & \\
\hline Myxofibrosarcoma & $9(4.8 \%)$ & $3(1.7 \%)$ & \\
\hline Leiomyosarcoma & $7(3.7 \%)$ & $19(10.7 \%)$ & \\
\hline PNET/Ewing & $6(3.2 \%)$ & $2(1.1 \%)$ & \\
\hline Rhabdomyosarcoma & $6(3.2 \%)$ & $2(1.1 \%)$ & $<0.001$. \\
\hline
\end{tabular}


Table 5: Patient characteristics per subgroup (Continued)

\begin{tabular}{lcc}
\hline Chondrosarcoma & $6(3.2 \%)$ & $3(1.7 \%)$ \\
$\begin{array}{l}\text { Dermatofibrosarcoma } \\
\text { protuberans }\end{array}$ & $4(2.1 \%)$ & $16(9.0 \%)$ \\
$\begin{array}{l}\text { Uterine } \\
\text { Leiomyosarcoma }\end{array}$ & $5(2.7 \%)$ & $7(3.9 \%)$ \\
$\begin{array}{l}\text { Osteosarcoma } \\
\text { Kaposi Sarcoma }\end{array}$ & $5(2.7 \%)$ & $6(3.4 \%)$ \\
Synovialosarcoma & $5(2.7 \%)$ & $13(7.3 \%)$ \\
Angiosarcoma & $5(2.7 \%)$ & $2(1.1 \%)$ \\
$\begin{array}{l}\text { Unclassified malignant } \\
\text { tumor }\end{array}$ & $3(1.6 \%)$ & $7(3.9 \%)$ \\
Other & $7(3.7 \%)$ & $7(3.9 \%)$ \\
\hline
\end{tabular}

ogists in the RA region took part in the study and full comprehensiveness was achieved. However, to achieve such a successful recruitment, many requirements must be met. In particular, there must be a key opinion leader and expert pathologist with recognized expertise in the field. Financial support to the pathologists participating in the study also seems essential. Finally, it is important, to keep the pathologists informed through regular meetings and newsletters. They must be involved and get feedback about the final diagnosis of their patient as well as about the advancement of the study. Cancer network participation can facilitate the involvement of pathologists and ensure exhaustiveness. It is well established in sarcoma pathology that "expert" opinion is not always absolutely convergent, though often different conceptualizations of a tumor do not necessarily generate different treatment implications. With the help of CONTICANET (CONnective TIssue CAncer NETwork), a similar prospective study has been initiated in the Aquitaine (France) and Venetia (Italy) regions to compare the rate of diagnostic discordance and confirm our conclusions. The correlation between concordance and free survival will be essentially evaluated on grade II/III tumors. The assessment of concordance is important for the patient for its impact on the diagnosis. The optimal diagnosis but also the optimum treatments (R0, radiotherapy decision) have an important role. Their prognostic value will be determinate in another article.

\section{Conclusion}

In conclusion, the inexperience of non-specialized pathologists with the multitude and complexity of sar-

\section{Table 6: Comparison of concordance results in the two groups}

\begin{tabular}{|c|c|c|c|}
\hline & Requested SO group & Control group & $p$ \\
\hline Included patients & $188(100 \%)$ & $178(100 \%)$ & \\
\hline \multicolumn{4}{|l|}{ Concordance } \\
\hline Zero & $53(28.2 \%)$ & $17(9.6 \%)$ & \\
\hline Partial & $53(28.2 \%)$ & $44(24.7 \%)$ & $<0.001$ \\
\hline Full & $82(43.6 \%)$ & $117(65.7 \%)$ & \\
\hline Included patients & $106(100 \%)$ & $61(100 \%)$ & \\
\hline \multicolumn{4}{|l|}{ Type of discordance } \\
\hline Subtype alone & $10(9.4 \%)$ & $7(11.5 \%)$ & \\
\hline Grade alone & $31(29.2 \%)$ & $37(60.7 \%)$ & \\
\hline Histological type alone & $27(25.5 \%)$ & $12(19.7 \%)$ & $<0.001$ \\
\hline Grade + Subtype & $13(12.3 \%)$ & $0(0 \%)$ & \\
\hline $\begin{array}{l}\text { Grade + Histological } \\
\text { type }\end{array}$ & $25(23.6 \%)$ & $5(8.2 \%)$ & \\
\hline
\end{tabular}


coma tumors, and the non availability of new molecular diagnostic tools are the most important factors accounting for diagnosis discrepancies. A centralized pathological review, a rapid and efficient help with access to molecular biology analysis seem of vital importance in these rare tumors. More efficient information and education of the pathologists also seems essential to ensure accurate diagnosis and grading [31].

\section{Additional material}

Additional file 1 Table S1: Grade concordance between groups using the Kappa test $(n=157)$.

Additional file 2 Table S2: Characteristics of patients per type of laboratory and type of tumor sample.

\section{Competing interests}

I declare that all authors disclose any financial and personal relationships with other people or organisations that could inappropriately influence (bias) their work. We would like just specify that Dr Dominic Cellier is the scientific relationship director of Merck-Serono. Merck-Serono is our financial support.

\section{Authors' contributions}

AL: Data collection, data analyse, interpretation data, statistical analyse, article writing; FD: Data collection, data analyse, interpretation data, written participation; DR-V: Data collection, histological review, interpretation data, final article review; A-VD: Data collection, histological review, interpretation data, final article review; DC: Study design, administrative participation, final article review; FG: Data collection, administrative participation, final article review; DS: Data collection, data analyse, final article review; PB: Data collection, administrative participation, final article review; GDL: Data collection, administrative participation, final article review; J-YB: Project conception, study design, data collection, final article review; IR-C: Project conception, study design, data collection, statistical analyse, final article review. All authors read and approved the final manuscript

\section{Acknowledgements}

The authors are grateful to Marie-Dominique Reynaud for editing assistance, to the data managers Muriel Rogasik and Philippe Cousin, and to all pathologists of the Rhone-Alpes region for their active collaboration in the study: Dr Agard Catherine, Dr Allias-Montmayeur Fabienne, Dr Angonin Régis, Dr Augros Marylin, Dr Bailly Christiane, Dr Balme Brigitte, Dr Bancel Brigitte, Dr Barnoud Raphaelle, Dr BenLagha Nadia, Dr Benabidallah Samir, Dr Berger Gerard, Dr Beschet Isabelle, Dr Beurlet Jacques, Dr Billard Françoise, Dr Bland Vincent, Dr Bonin Anne-Marie, Dr Bottero Noelle, Dr Bourloux Jocelyne, Dr Bouvier Raymonde, Dr Bozon Catherine, Dr Brambilla Elisabeth, Dr Bringeon Béatrice, Dr Buenerd Annie, Dr Cantero Brigitte, Dr Cavaillés Catherine, Dr Chalabreysse Lara, Dr Chalabreysse Philippe, Dr Chambonniere Marie-Laure, Dr Chanoz Jacques, Dr Chanoz-Poulard Geneviève, Dr Chassagne-Clément Catherine, Dr Chevallier Michèle, Dr Chouvet Brigitte, Dr Ciapa Agnès, Dr Claret-Tournier Catherine, Dr Clemenson Alix, Dr Collardeau Frachon Sophie, Dr Corrand-Faure Anne, Dr Corsois Laurent, Dr Crozes Carole, Dr Cruel Thierry, Dr David Catherine, Dr De la Fouchardiere Arnaud, Dr Decaussin-Petrucci Myriam, Dr Decouvelaere Anne-Valérie, Dr Denier Jean-François, Dr Der Garabedian Philiberte, Dr Derolland Philippe, Dr Descombes-Thivolet Brigitte, Dr Dieny Anne-Florence, Dr Dijoud Frederique, Dr Donne Chantal, Dr Donsbeck Anne-Valérie, Dr Douchet Catherine, Dr Dumollard Jean, Dr Dusserre Isabelle, Dr Economides-Jarsaillon Ariane, Dr Elbaz Nadine, Dr Fabre Blandine, Dr Faisant Monique, Dr Faure Anne, Dr Faure Claire, Dr Faysse Michaelie, Dr Feutry Catherine, Dr Fontaniere Bernard, Dr Frachon-Collardeau Sophie, Dr Gasnier Plaweski F, Dr Gentil-Perret Anne, Dr Glehen Alexandra, Dr Godard William, Dr Godeneche Janique, Dr Gouarderes Catherine, Dr Gouzy-Grosjean Fabienne, Dr Griot Annick, Dr Guillaubey Colette, Dr Guillaud Catherine, Dr Herve-Nicollet Catherine, Dr Hervieu Valérie, Dr Isaac Sylvie, Dr Istier Luc, Dr Jouvet Anne, Dr Kanitakis Jean, Dr Kermanac'h Pascale, Dr Khaddage Abir, Dr Klein Laurence, Dr Knopf Jean-François, Dr Koeb MarieHélène, Dr Labadie Michel, Dr Lantuejoul Sylvie, Dr Laurent Isabelle, Dr Lauro
Carole, Dr Le Breton Frédérique, Dr Lucht-Versini Pascale, Dr Mabrut Marianne Dr Machayekhi Jean-Pierre, Dr Maisonneuve Martine, Dr Maisonneuve-Gilly Dominique, Dr Mege-Lechevallier Florence, Dr Meyronet David, Dr Morcillo J-L, Dr Muller Bernard, Dr Muller Christine, Dr Neyra Monique, Dr Pasquier Dominique, Dr Perrot Guy, Dr Pialat Jean, Dr Picchetti Nicole, Dr Pinel Nicole, Dr Pocachard, Dr Pugens Gilles, Dr Ranchère-Vince Dominique, Dr Reis Borges Ruth, Dr Richard Jacques, Dr Roux Jean-Jacques, Dr Roux-Gilly Marie-Georges, Dr Saint Genis Luc, Dr Saint-Pierre Ghislaine, Dr Salameire Dimitri, Dr Salle Monique, Dr Salon Caroline, Dr Serain Francois, Dr Soubeyrand Marie-Sophie, Dr Streichenberger Nathalie, Dr Sturm Nathalie, Dr Suignard Yves, Dr Terdjman Pierre, Dr Treilleux Isabelle, Dr Vancina Serge, Dr Vaunois Brigitte, Dr Vercherin Axelle, Dr Vitetta Franck, Dr Vock-Bonnet Marthe, Dr Youssef Nelly, Pr Devouassoux Mojgan, Pr Pasquier Basile, Pr Peoc'h Michel, Pr Scoazec Jean-Yves, Pr Thivolet Bejoui Francoise.

Financial support: Merck Serono, National League against Cancer (Ain and Rhône committees), CONTICANET network.

Presented in part at 2008 CTOS.

\section{Author Details}

${ }^{1}$ Centre Léon Bérard, 28 rue Laennec - 69008 Lyon; France, 2 INSERM EA 4129 « SIS », 28 rue Laennec - 69008 Lyon, France, ${ }^{3}$ ONCORA network, Réseau Oncologie Rhône-Alpes BIOPARC/ADENINE - 60 Avenue Rockefeller, 69373 LYON Cedex 08, France, ${ }^{4}$ CONCORDE network, Réseau Oncologie Rhône-Alpes BIOPARC/ADENINE - 60 Avenue Rockefeller, 69373 LYON Cedex 08, France, 5ARC'ALPIN network, Unité de Concertation et de Recherche pour le Traitement des Affections Cancéreuses, CHU A. Michallon BP217 38043 GRENOBLE, France, 6 Institut de Cancerologie de la Loire, 108 Bis av. Albert Raimond 42270 Saint Priest en Jarez, France, ${ }^{7}$ Merck Serono, 37 rue Saint Romain - 69008 Lyon, France and 8INSERM U590 Cytokine et Cancer, 28 rue Laennec - 69008 Lyon, France

Received: 24 September 2009 Accepted: 19 April 2010

Published: 19 April 2010

\section{References}

1. Menegoz F, Black RJ, Arveux P, Magne V, Ferlay J, Buemi A, et al:: Cancer incidence and mortality in France in 1975-95. Eur J Cancer Prev 1997, 6(5):442-66.

2. Clark MA, Fisher C, Judson I, Thomas JM: Soft-tissue sarcomas in adults. NEngl J Med 2005, 353(7):701-11.

3. Ray-Coquard I, Thiesse P, Ranchere-Vince D, Chauvin F, Bobin JY, Sunyach MP, et al:: Conformity to clinical practice guidelines, multidisciplinary management and outcome of treatment for soft tissue sarcomas. Ann Oncol 2004, 15(2):307-15.

4. Fletcher CD, Unni KK, Mertens F: WHO classification of tumors. Pathology and genetics. In Tumors of Soft Tissue and Bone IARC press; 2002.

5. Casali PG, Jost L, Sleijfer S, Verweij J, Blay JY: Soft tissue sarcomas: ESMO clinical recommendations for diagnosis, treatment and follow-up. Ann Oncol 2008, 19(Suppl 2):ii89-ii93.

6. Arbiser ZK, Folpe AL, Weiss SW: Consultative (expert) second opinions in soft tissue pathology. Analysis of problem-prone diagnostic situations. Am J Clin Pathol 2001, 116(4):473-6.

7. Coindre JM, Nguyen BB, Goussot JF, De MI, Maree D, De Mascarel A, et al: [Histological changes after chemotherapy of soft tissue sarcomas in the adult]. Ann Pathol 1985, 5(2):95-9.

8. Coindre JM, Trojani M, Contesso G, David M, Rouesse J, Bui NB, et al: Reproducibility of a histopathologic grading system for adult soft tissue sarcoma. Cancer 1986, 58(2):306-9.

9. Harris M, Hartley AL, Blair V, Birch JM, Banerjee SS, Freemont AJ, et al: Sarcomas in north west England: I. Histopathological peer review. BrJ Cancer 1991, 64(2):315-20.

10. Katenkamp D: Cellular heterogeneity. Explanation for changing of tumor phenotype and biologic behavior in soft tissue sarcomas. Pathol Res Pract 1988, 183(6):698-705.

11. Tomaszewski JE, Bear HD, Connally JA, Epstein Jl, Feldman M, Foucar K, et al:: Consensus conference on second opinions in diagnostic anatomic pathology. Who, What, and When. Am J Clin Pathol 2000, 114(3):329-35.

12. Lind AC, Bewtra C, Healy JC, Sims KL: Prospective peer review in surgical pathology. Am J Clin Pathol 1995, 104(5):560-6. 
13. Kronz JD, Westra WH, Epstein Jl: Mandatory second opinion surgical pathology at a large referral hospital. Cancer 1999, 86(11):2426-35.

14. Ducimetiere A, Lurkin D, Ranchere-Vince P, Biron M, Peoch L, Istier D, Salameire P, Chalabreysse J, Blay Y, Ray-Coquard I: Exhaustive prospective collection of new sarcomas: Report of an unexpectedly high incidence. Journal of Clinical Oncology, 2007 ASCO Annual Meeting Proceedings (Post-Meeting Edition) 2007, 25(No 18S (June 20 Supplement)):20513.

15. Berger C, Trombert-Paviot B, Mitton N, Frappaz D, Galambrun C, Plantaz D, et al:: [Childhood cancer incidence and survival rates in the RhoneAlpes regional paediatric registry 1987-1999]. Arch Pediatr 2006 13(2):121-9

16. Freycon F, Trombert-Paviot B, Casagranda L, Bertrand $Y$, Plantaz D, MarecBerard P: Trends in treatment-related deaths (TRDs) in childhood cancer and leukemia over time: a follow-up of patients included in the childhood cancer registry of the Rhone-Alpes region in France (ARCERRA). Pediatr Blood Cancer 2008, 50(6):1213-20.

17. Guillou L, Coindre JM, Bonichon F, Nguyen BB, Terrier P, Collin F, et al:: Comparative study of the National Cancer Institute and French Federation of Cancer Centers Sarcoma Group grading systems in a population of 410 adult patients with soft tissue sarcoma. J Clin Oncol 1997, 15(1):350-62.

18. Cohen J: A coefficient of agreement for nominal scales. Educ Psychol Meas 1960, 20:27-46.

19. Fleiss JL, Cohen J, Everitt BS: Large sample standard errors of kappa and weighted kappa. Psychol Bull 1969, 72:323-327.

20. Singer S, Corson JM, Demetri GD, Healey EA, Marcus K, Eberlein TJ: Prognostic factors predictive of survival for truncal and retroperitoneal soft-tissue sarcoma. Ann Surg 1995, 221(2):185-95.

21. Singer S, Baldini EH, Demetri GD, Fletcher JA, Corson JM: Synovial sarcoma: prognostic significance of tumor size, margin of resection, and mitotic activity for survival. J Clin Oncol 1996, 14(4):1201-8.

22. Enzinger FM: Soft tissue tumours. 4th edition. Weiss SW. St Louis: Mosby; 2001.

23. Reichardt P: High-dose chemotherapy in adult soft tissue sarcoma. Crit Rev Oncol Hematol 2002, 41(2):157-67.

24. Coindre JM: [Recommendations for anatamo-pathologic management of soft tissue sarcomas in the adult. Pathologists of the FNCLCC Sarcoma Group (Federation Nationale des Centres de Lutte Contre le Cancer)]. Ann Pathol 1998, 18(6):505-11.

25. Coindre JM: Histologic grading of adult soft tissue sarcomas. Verh Dtsch Ges Pathol 1998, 82:59-63.

26. Hasegawa T, Yamamoto S, Nojima T, Hirose T, Nikaido T, Yamashiro K, et al:: Validity and reproducibility of histologic diagnosis and grading for adult soft-tissue sarcomas. Hum Pathol 2002, 33(1):111-5.

27. Lehnhardt M, Daigeler A, Hauser J, Puls A, Soimaru C, Kuhnen C, et al:: The value of expert second opinion in diagnosis of soft tissue sarcomas. J Surg Oncol 2008, 97(1):40-3.

28. Bridge JA, Sandberg AA: Cytogenetic and molecular genetic techniques as adjunctive approaches in the diagnosis of bone and soft tissue tumors. Skeletal Radiol 2000, 29(5):249-58.

29. Coindre JM: Immunohistochemistry in the diagnosis of soft tissue tumours. Histopathology 2003, 43(1):1-16.

30. Ladanyi M, Bridge JA: Contribution of molecular genetic data to the classification of sarcomas. Hum Pathol 2000, 31(5):532-8.

31. Ordóñez NG: Application of immunocytochemistry in the diagnosis of soft tissue sarcomas: a review and update. Adv Anat Pathol 1998, 5:67-85.

32. Yamaguchi $U$, Hasegawa $T$ : [Pathological evaluation of soft tissue sarcoma for diagnosis, prognosis and treatment]. Gan To Kagaku Ryoho 2004, 31(9):1340-5.

33. Meis-Kindblom JM, Bjerkehage B, Bohling T, Domanski H, Halvorsen TB, Larsson O, et al:: Morphologic review of 1000 soft tissue sarcomas from the Scandinavian Sarcoma Group (SSG) Register. The peer-review committee experience. Acta Orthop Scand Supp/ 1999, 285:18-26.

34. Presant CA, Russell WO, Alexander RW, Fu YS: Soft-tissue and bone sarcoma histopathology peer review: the frequency of disagreement in diagnosis and the need for second pathology opinions. The Southeastern Cancer Study Group experience. J Clin Oncol 1986, 4(11):1658-61.
35. Randall RL, Bruckner JD, Papenhausen MD, Thurman T, Conrad EU III: Errors in diagnosis and margin determination of soft-tissue sarcomas initially treated at non-tertiary centers. Orthopedics 2004, 27(2):209-12

36. Shiraki M, Enterline HT, Brooks JJ, Cooper NS, HirschI S, Roth JA, et al: Pathologic analysis of advanced adult soft tissue sarcomas, bone sarcomas, and mesotheliomas. The Eastern Cooperative Oncology Group (ECOG) experience. Cancer 1989, 64(2):484-90.

37. Westra WH, Kronz JD, Eisele DW: The impact of second opinion surgical pathology on the practice of head and neck surgery: a decade experience at a large referral hospital. Head Neck 2002, 24(7):684-93.

38. Matasar MJ, Shi W, Silberstien J, et al.: Expert second opinion pathology review of lymphoma in the Era of the world health organization classification. Blood 2007

39. Piver MS, Tsukada Y, Werness BA, Dicioccio RA, Whittemore AS, Ponder BA: Comparative study of ovarian cancer histopathology by registry pathologists and referral pathologists: a study by the Gilda Radner Familial Ovarian Cancer Registry. Gynecol Oncol 2000, 78(2):166-70.

\section{Pre-publication history}

The pre-publication history for this paper can be accessed here: http://www.biomedcentral.com/1471-2407/10/150/prepub

\section{doi: 10.1186/1471-2407-10-150}

Cite this article as: Lurkin et al., Epidemiological evaluation of concordance between initial diagnosis and central pathology review in a comprehensive and prospective series of sarcoma patients in the Rhone-Alpes region BMC Cancer 2010, 10:150

\section{Submit your next manuscript to BioMed Centra and take full advantage of:}

- Convenient online submission

- Thorough peer review

- No space constraints or color figure charges

- Immediate publication on acceptance

- Inclusion in PubMed, CAS, Scopus and Google Scholar

- Research which is freely available for redistribution

Submit your manuscript at www.biomedcentral.com/submit
C) Biomed Central 